\title{
Jan Samotnik z Apamei, $O$ modlitwie
}

\section{Wstęp}

Jan z Apamei ${ }^{1}$, znany również jako Jan Samotnik (Jan Ihidaya, Yohannan Ihidaya) ${ }^{2}$, to syryjski pisarz tworzący najprawdopodobniej $\mathrm{w}$ drugiej połowie $\mathrm{V}$ wieku ${ }^{3}$ związany $\mathrm{z}$ miastem Apamea, starożytnym ośrodkiem położonym nad rzeką Orontes w odległości około $90 \mathrm{~km}$ od Antiochii ${ }^{4}$. Jan, obok Numeniosa z Apamei, filozofa z II wieku, jest bodaj najbardziej znaną postacią związaną z tym miastem.

W przeszłości postać Jana Samotnika była mylona z dwoma innymi Janami oskarżanymi o herezję ${ }^{5}$, a czasami można było przeczytać o nim

1 R.A. Kitchen, Yohannan Ihidaya. John the Solitary of Apamea, w: Gorgias Encyclopedic Dictionary of Syriac Heritage, red. S.P. Brock - A.M. Butts - G.A. Kiraz L. Van Rompay, Piscataway 2001, s. 442.

2 Syryjski termin iḥidaya jest dość trudny do przetłumaczenia, ponieważ posiada szereg różnych odniesień ('samotny, jeden, jedyny, pojedynczy, prosty, niezłożony, niezamężna, nieżonaty, sam'). Gdy jest używany w stosunku do Jezusa Chrystusa, oznacza 'Jednorodzony, Jedyny'. Terminu iḥidaya używa się również na określenie wczesnej formy życia monastycznego, praktykowanej na terenach starożytnej Syrii. Ihidaye byli to samotnicy, których pragnieniem było wieść ,proste” życie upodobniające ich do Chrystusa, Jedynego Syna Ojca. Por. S. Brock, Spirituality in the Syriac Tradition, Kottayam 1989, s. 50-52; R.A. Kitchen, Ihidaya, w Gorgias Encyclopedic Dictionary of Syriac Heritage, red. S.P. Brock - A.M. Butts - G.A. Kiraz - L. Van Rompay, Piscataway 2001, s. 208.

3 S.P. Brock, John the Solitary. On Prayer, JTS 30/1 (1979) s. 84.

4 L. Van Rompay, Apamea, w: Gorgias Encyclopedic Dictionary of Syriac Heritage, red. S.P. Brock - A.M. Butts - G.A. Kiraz - L. Van Rompay, Piscataway 2001, s. 23-24.

5 W źródłach historycznych można znaleźć informację, że biskup Filoksenos z Mabbug przeciwstawiał się poglądom pewnego „Jana z Egiptu” oraz że synod z lat 786787 potępił naukę „Jana z Apamei”. Por. R. Duval, Anciennes Littératures Chrétiennes. II. La littérature Syriaque, Paris 1907, s. 312; S.P. Brock, A Brief Outline of Syriac Literature, Kottayam 1997, s. 31-32. 
jako o Janie z Lykopolis ${ }^{6}$. Dzisiaj badacze skłaniają się do tego, aby uznać Jana Samotnika i Jana z Apamei za jedną i tę samą osobę niemającą nic wspólnego z Janami oskarżonymi o nieprawowierność poglądów. Zbiór tekstów Jana Samotnika z Apamei, który mamy do dyspozycji, jest stosunkowo niewielki, są to małe dzieła dotyczące głównie życia duchowego. Jan Samotnik z Apamei jest przedstawiany w literaturze dotyczącej syryjskiej tradycji chrześcijaństwa przede wszystkim jako specjalista od duchowości $^{7}$. Charakterystyczną cechą jego myśli jest trójczłonowy podział, który wprowadza zarówno, gdy mówi o etapach (porządkach) rozwoju życia duchowego, jak i wtedy, gdy mówi o poziomach duchowych, które osoba duchowa osiąga, przechodząc przez poszczególne etapy. Etapy rozwoju duchowego to etap związany z ciałem (pagrānuthā, w którym główną rolę odgrywa dyscyplina zewnętrzna), następnie z duszą (nafšānuthā, tutaj wysiłek zwrócony jest ku porządkowaniu myśli) i na koniec z duchem (ruhānuthā). Poziomy, na które wspina się osoba, to czystość (dakyutā), spokój (̌̌apyutā), doskonałość (gmirutā) ${ }^{8}$. Ta ostatnia, doskonałość, jest osiągalna dopiero w Królestwie Bożym, w tym życiu można jej doświadczyć jedynie przez krótkie chwile, które zapowiadają to, czym będzie się żyło w przyszłości ${ }^{9}$. Przywołana wyżej nauka Jana Samotnika wywarła wpływ na niektórych późniejszych autorów syryjskich ${ }^{10}$. Jak zaznacza R.A. Kitchen, to prawdopodobnie fakt, że mylono go z innymi Janami oskarżanymi o herezję, sprawił, że mamy do dyspozycji stosunkowo niewielką ilość jego pism, z których pozostało głównie kilka listów, niewielkie dzieła o modlitwie i dwa komentarze do ksiąg biblijnych - do Księgi Koheleta i Księgi Hioba, których autentyczność podlega dyskusji ${ }^{11}$.

6 Por. A. Baumstark, Geschichte der syrischer Literatur, Bonn 1922, s. 88-90. W literaturze można znaleźć także imię „Pseudo-Jan z Lykopolis”. Zob. I.O. de Urbina, Patrologia Syriaca, Roma 1958, s. 222-223.

7 Por. Brock, A Brief Outline, s. 31-32; Brock, Spirituality, s. 23-24; P. Bettiolo, Lineamenti di patrologia siriaca, w: Complementi interdisciplinari di patrologia, red. A. Quacquarelli, Roma 1989, s. 544-547.

8 Kitchen, Yohannan Ihidaya, s. 442.

9 Zob. P. Harb, Doctrine spirituelle de Jean Le Solitaire, Jean d'Apameé, ParOr 2/2 (1979) s. 225-260; P. Bettiolo, Syriac Literature, w: Patrology V. The Eastern Fathers from the Council of Chalcedon (451) to John of Damascus (†750), ed. A. di Bernardino, Cambridge 2006, s. 454-456; Brock, Spirituality, s. 23-24.

10 Zob. D.R. Acosta, John of Apamea. His Identity and his Dualistic Anthropological Conception, „Teología y cultura” 16 (2014) s. 106-121. W tym artykule Acosta nie zgadza się z ogólnie przyjętym poglądem. Według niego Jan Samotnik z Apamei używa trójczłonowego podziału tylko w niektórych pismach i nie może to być uznane za główną cechę charakteryzującą jego poglądy.

11 Kitchen, Yohannan Ihidaya, s. 442; Brock, A Brief Outline, s. 31-32. 
Tekst, którego polskie thumaczenie przedstawiamy poniżej, jest krótką rozprawą o cichej modlitwie. Temat ten jest dość rzadko poruszany przez starożytnych pisarzy, dla których życie modlitwy oznaczało przede wszystkim modlitwę psalmami czy inne formy recytacji Słowa Bożego ${ }^{12}$. Syryjscy pisarze poruszali temat cichej modlitwy już w IV wieku (por. np. Afrahat, Demonstratio quarta. De Oratione ${ }^{13}$ ), głównie przy okazji komentowania słów Jezusa z Kazania na Górze o tym, że trzeba wejść do izby i tam się modlić (Mt 6,6 $)^{14}$. Punktem wyjścia dla Jana Samotnika jest natomiast fragment z Ewangelii św. Jana (J 4,21-24), w którym jest mowa o czczeniu Ojca „w duchu i w prawdzie”, oraz werset 1Kor 14,15. Jan Samotnik pisze, że modlący się człowiek jest zapraszany do tego, aby stopniowo przechodzić od modlitwy głosem do modlitwy ciszy. Nie deprecjonuje jednak modlitwy na głos, o ile tylko nie jest ona bezmyślną mechaniczną recytacją, ale okazją do tego, aby spotkać się ze Słowem. To Słowo staje się ciałem w modlącym się.

Tekst Jana Samotnika o modlitwie został opublikowany przez Brocka w artykule zamieszczonym w „Journal of Theological Studies”'15. Brock opiera swoje wydanie na pochodzącym z IX wieku manuskrypcie obecnie znajdującym się w zbiorach British Library (Add. 17172). Przytacza warianty tekstualne obecne $\mathrm{w}$ innych manuskryptach zawierających ten krótki utwór. Przeanalizowane zostały przez niego następujące rękopisy: British Library Add. 18817 z IX wieku; Mingana syr. 14 z 1898 roku; Vatican syr. 126 z 1223 roku oraz British Library Or 6714, w którym tekst Jana Samotnika z Apamei pojawia się jako fragment dzieła Abrahama z Nathpar - jest do niego włączony w całości ${ }^{16}$. Wydaniu tekstu przygotowanego przez Brocka towarzyszy tłumaczenie na język angielski. Oksfordzki ekspert thumaczy również najważniejsze warianty tekstualne.

Dzieło $O$ modlitwie zostało opublikowane jeszcze raz w 1981 roku przez włoskiego uczonego Paolo Bettiolo ${ }^{17}$. Bettiolo zainteresował się manuskryptem przechowywanym w British Museum (BM Add. 12.167), który miał zawierać kilka pism Filoksena z Mabbug. Jedno z nich jest jednak tym samym tekstem o modlitwie, który Brock opublikował jako dzieło Jana Samotnika z Apamei. Bettiolo wskazuje w swoim artykule dodatkowe argumenty, które przemawiają za Janowym, a nie Filoksenowym autorstwem tego tekstu.

12 Por. np. B. Bitton-Ashkelony, ,More Interior than the Lips and the Tongue”: John of Apamea and Silent Prayer in Late Antiquity, JECS 20/2 (2012) s. 303-331.

13 Afrahat, $O$ modlitwie (Demonstratio quarta. De Oratione, PSyr I,137-182), „Śląskie Studia Historyczno-Teologiczne” 43/1 (2010) s. 31-44.

14 Por. Bitton-Ashkelony, ,, More Interior than the Lips and the Tongue”, s. 318-319.

15 S.P. Brock, John the Solitary. On Prayer, JTS 30/1 (1979) s. 84-101.

16 Brock, John the Solitary. On Prayer, s. 85.

17 P. Bettiolo, Sulla Preghiera: Filosseno o Giovanni, „Le Muséon” 94 (1981) s. 75-89. 
Tekst z manuskryptu BM Add. 12.167, który publikuje Bettiolo, składa się $\mathrm{z}$ trzech fragmentów, $\mathrm{z}$ których trzeci jest tożsamy $\mathrm{z}$ tym, który opublikował wcześniej Brock. Dwa krótsze fragmenty, poprzedzające go, również dotyczą modlitwy, ale Bettiolo nie wypowiada się na temat ich autorstwa.

Niniejsze tłumaczenie opiera się na tekście wydanym przez Brocka, a zatem na manuskrypcie British Library Add. 17172. W przypisach dolnych oddano tłumaczenia najważniejszych wariantów tekstualnych pochodzących głównie z manuskryptu British Library Or 6714 (przytoczonych w wydaniu Brocka) i z manuskryptu z British Museum, BM Add. 12.167 (przedstawionych w wydaniu Bettiolo).

\section{Wydania tekstu}

\section{Wydanie z przekładem na angielski}

Brock S.P., John the Solitary. On Prayer, JTS 30/1 (1979) s. 89-96.

\section{Wydanie z przekładem na włoski}

Bettiolo P., Sulla preghiera: Filosseno o Giovanni?, „Le Muséon” 94/1-2 (1981) s. 75-89.

\section{Bibliografia}

\section{Źródła}

Aphraates, Demonstratio quarta. De Oratione, PSyr I, 137-182, tł. A. Uciecha, Afrahat, O modlitwie, „Śląskie Studia Historyczno-Teologiczne” 43/1 (2010), s. 31-44.

\section{Opracowania}

Acosta D.R., John of Apamea. His Identity and his Dualistic Anthropological Conception, „Teología y cultura” 16 (2014) s. 106-121.

Baumstark A., Geschichte der syrischer Literatur, Bonn 1922. 
Bettiolo P., Lineamenti di patrologia siriaca, w: Complementi interdisciplinari di patrologia, red. A. Quacquarelli, Roma 1989, s. 544-547.

Bettiolo P., Syriac Literature, w: Patrology V. The Eastern Fathers from the Council of Chalcedon (451) to John of Damascus (†750), ed. A. di Bernardino, Cambridge 2006, s. 454-456.

Bitton-Ashkelony B., ,, More Interior than the Lips and the Tongue”: John of Apamea and Silent Prayer in Late Antuquity, JECS 20/2 (2012) s. 303-331.

Brock S., Spirituality in the Syriac Tradition, Kottayam 1989.

Brock S., A Brief Outline of Syriac Literature, Kottayam 1997.

Brock S.P. - Kiraz A.G., Gorgias Concise Syriac-English, English-Syriac Dictionary, Piscataway 2015.

Duval R., Anciennes Littératures Chrétiennes. II. La littérature Syriaque, Paris 1907.

Harb P., Doctrine spirituelle de Jean Le Solitaire, Jean d'Apameé, ParOr 2/2 (1979) s. $225-260$.

Kitchen R.A., Ihidaya, w: Gorgias Encyclopedic Dictionary of Syriac Heritage, red. S.P. Brock - A.M. Butts - G.A. Kiraz - L. Van Rompay, Piscataway 2001, s. 208.

Kitchen R.A., Yohannan Ihidaya. John the Solitary of Apamea, w: Gorgias Encyclopedic Dictionary of Syriac Heritage, red. S.P. Brock - A.M. Butts - G.A. Kiraz - L. Van Rompay, Piscataway 2001, s. 442.

Payne Smith R., Thesaurus Syriacus, t. 1-2, Oxonii 1879.

Van Rompay L., Apamea, w: Gorgias Encyclopedic Dictionary of Syriac Heritage, red.

S.P. Brock - A.M. Butts - G.A. Kiraz - L. Van Rompay, Piscataway 2001, s. 23-24. de Urbina I.O., Patrologia Syriaca, Roma 1958, s. 222-223.

\section{Przekład ${ }^{18}$}

1. Nie myśl sobie, bracie, że modlitwa ${ }^{19}$ składa się tylko ze słów. I nie myśl, że można się jej [za pomocą] ${ }^{20}$ słów nauczyć. Posłuchaj mnie ${ }^{21}$ za-

18 Podstawą przekładu jest tekst syryjski zamieszczony w: S.P. Brock, John the Solitary. On Prayer, JTS 30/1 (1979) s. 89-96. Tłumaczenie oparte jest w całości na wydaniu Brocka według manuskryptu British Library Add. 17172. W przypisach dolnych podano tłumaczenie tylko niektórych najważniejszych wariantów tekstualnych wskazanych przez Brocka w cytowanej powyżej pracy i przez Bettiolo w: P. Bettiolo, Sulla preghiera: Filosseno o Giovanni?, „Le Muséon” 94/1-2 (1981) s. 75-89.

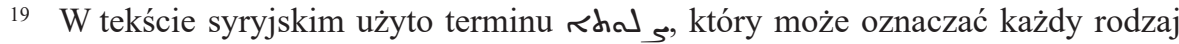
modlitwy, zarówno modlitwę liturgiczną, jak i prywatną. Por. R. Payne Smith, Thesaurus Syriacus, 3401 (dalej cytowany jako Thesaurus).

20 Słowa umieszczone w nawiasach kwadratowych pochodzą od autora niniejszego opracowania.

21 Manuskrypt British Library Or. 6714 ma tutaj wariant „naszego Pana”. 
tem, [posłuchaj] tego, co jest prawdziwe: modlitwa duchowa ${ }^{22}$ nie staje się doskonała ani ze względu na naukę, ani z powodu powtarzania słów.

[A dzieje się tak] dlatego, że [nie] modlisz się do człowieka, przed którym możesz powtarzać dobrze ułożone słowa, ale kierujesz poruszenia twojej modlitwy do Tego, który jest duchem ${ }^{23}$. Módl się zatem w duchu, skoro On jest duchem ${ }^{24}$.

2. Do tego, żeby w doskonały sposób modlić się do Boga, nie wymaga się żadnego [wyjątkowego] miejsca. Do doskonałej modlitwy ${ }^{25}$ nie potrzeba ani elokwencji języka, ani [specjalnego] miejsca, [bo] nasz Pan powiedział: „Nadchodzi godzina, że ani na tej górze, ani w Jerozolimie nie będziecie wielbić Ojca" (J 4,21). I o tym, że nie jest wymagane żadne specjalne miejsce ${ }^{26}$, nauczał także [gdy mówił], że „Ci, którzy czczą Ojca, powinni [Go] czcić w Duchu i w prawdzie" (J 4,23). A gdy uczył nas, dlaczego powinniśmy modlić się w taki sposób, to mówił: „Bóg jest Duchem” (J 4,24), [a zatem] powinien być czczony w duchu, duchowo. A i Paweł naucza nas o takiej modlitwie i psalmodii ${ }^{27} \mathrm{w}$ duchu. Gdy się modlimy i śpiewamy psalmy, to [czasami zadajemy sobie pytanie]: „Co będę robił?”. [Paweł] mówi: „Będę się modlił w duchu i będę się modlił również W moim umyśle ${ }^{28}$. Będę śpiewał psalmy w duchu i będę śpiewał psalmy w umyśle” (1Kor 14,15). „Duch i umysł” - powiada - to w nich człowiek będzie się modlił, będzie śpiewał psalmy Bogu i wielbił Go.

Nie wspomina się natomiast o języku, a to dlatego właśnie, że modlitwa jest duchowa, bardziej wewnętrzna niż język. Jest bardziej wewnętrzna, jest głębsza niż to, co na ustach. Jest bardziej wewnętrza niż słowa, i [idzie] dalej niż pieśń. I gdy człowiek modli się taką modlitwą i jest zanurzo-

22 Jan Samotnik używa tutaj sformułowania Khewai Khal s. Przymiotnik Khewai, oznacza coś duchowego. Por. Thesaurus, 3853: „spiritualis”. Peszitta oddaje nim np.

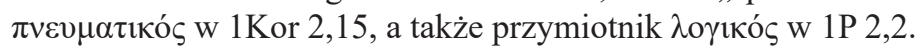

23 Manuskrypt BM Add. 12.167 dodaje w tym miejscu: ,ani wcielonym, ani złożonym".

24 Syryjski termin мa może zostać użyty na określenie bytów duchowych, jak i tego, co duchowe w człowieku. Por. Thesaurus, 3850-3853. Peszitta używa tego terminu w odniesieniu do Boga np. w J 4,24. Do tego wersetu odnosi się Jan Samotnik w kolejnych zdaniach swojego tekstu.

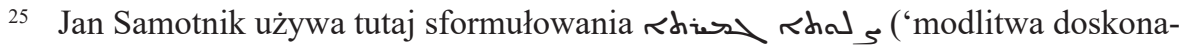
ła'). Można byłoby ten zwrot przetłumaczyć również jako 'modlitwa kompletna, modlitwa perfekcyjna'. Por. Thesaurus, 738-739.

26 BM Add. 12.167 ma tutaj wariant ,żadne słowo”.

27 Syryjskie słowo risa oznacza 'psalmodię' i może odnosić się zarówno do psalmów biblijnych, jak i do innych śpiewów, zwłaszcza liturgicznych. Por. Thesaurus, 1136.

28 W 1Kor 15,14 jest użyte słowo voṽs. Peszitta tłumaczy je tam terminem ('umysł, intelekt'). Por. Thesaurus, 1560. Tego samego terminu używa Jan Samotnik. 
ny [głębiej] niż słowa ${ }^{29}$, to staje w miejscu bytów duchowych ${ }^{30} \mathrm{i}$ aniołów. I bez słów, tak jak oni, śpiewa „Święty, święty, święty”. I jeśli zakończy taką modlitwę i zacznie modlitwę pieśni języka, to znajdzie się $e^{31}$ poza kręgiem aniołów i stanie się znowu zwykłym ${ }^{32}$ człowiekiem.

3. Kto zatem śpiewa w języku i w ciele i jest wytrwały w takim uwielbieniu w noc i za dnia, taki jest ,sprawiedliwy”. Kto zaś został uznany za godnego wejścia głębiej i śpiewa w duchu i w umyśle, ten zostaje nazwany „duchowym”. Bycie duchowym jest donioślejsze niż bycie sprawiedliwym. Ale można stać się „duchowym” dopiero po tym, jak się było „sprawiedliwym”.

Bo człowiek musi czcić Boga przez odpowiedni czas w zewnętrzny sposób: poszcząc, używając głosu do śpiewania psalmów, [spędzając] długi czas na kolanach, w nieustannych czuwaniach, na recytacji psalmów, przy ciężkich pracach, [zanosząc] błagania ${ }^{33}$, we wstrzemięźliwości, [znosząc] niedostatek jedzenia i w temu podobnych sprawach ${ }^{34}$.

Gdy dusza człowieka napełni się pamięcią o Bogu, bojaźnią i drżeniem na Jego imię, gdy jest pokorny przed każdym człowiekiem, tzn. uważa wszystkich innych za większych ${ }^{35}$ od siebie, dopiero wówczas będzie mógł śpiewać Bogu takim śpiewem, jakim chwalą go [osoby] „duchowe”. [Nawet wówczas] gdy widzi, co robi inny człowiek: popełnia cudzołóstwo, jest rozpustny, oszukuje innych, jest pijakiem ${ }^{36}$, [a mimo to] ciągle zachowuje się pokornie wobec niego i uważa go, nie tylko na zewnątrz, ale w najtajniejszej głębi swoich myśli ${ }^{37}$, za lepszego od siebie i idzie do tego, którego widział pośrodku wszystkich tych złych rzeczy, i korzy się przed nim i błaga: ,pomódl się za mnie, bo jestem grzesznikiem przed Panem i mam wielkie długi, i nie odpłaciłem Mu za żadną z tych rzeczy". Gdy zatem ktoś tak czyni lub czyni rzeczy o wiele większe niż te, o których

29 BM Add. 12.167 ma wariant ,, i ukrywa się przed światem”, British Library Or. 6714 natomiast - ,i jest doskonalszy”.

30 Należy rozumieć to wyrażenie jako synonim słowa ,anioł”. Por. Thesaurus, 3853.

31 Wariant w BM Add. 12.167 brzmi „wyszed””, w manuskrypcie British Library Or. 6714 natomiast - ,jest usuwany”.

32 BM Add. 12.167 ma tutaj „sprawiedliwym”, co lepiej komponuje się z następną sekcją tekstu.

33 Warirant w BM Add. 12.167 ma „w czuwaniach”.

34 British Library Or. 6714: ,i w innych temu podobnych sprawach odpowiednich dla jego sposobu życia, jak również w czuwaniu nad zmysłami”.

35 BM Add. 12.167: ,za lepszych”.

36 British Library Or. 6714: „mordercą, osobą bezczelną, oszczercą, bluźniercą albo osobą z grzechami jeszcze gorszymi niż te; to gdy widzi taka osobę".

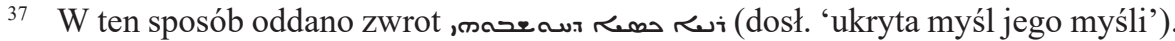


tu mówię, dopiero wówczas będzie mógł śpiewać Bogu takim śpiewem, jakim chwalą go [osoby] „duchowe”.

4. Ciszą ${ }^{38}$ jest Bóg. I tylko w ciszy można Mu śpiewać, i to taką pieśń, która jest Jego godna. Nie mówię tutaj o milczeniu ust. Jeśli język jakiegoś człowieka milczy, a nie wie on, jak wielbić w umyśle i w duchu, to taki jest bezczynny i staje się pełen złych myśli ${ }^{39}$ : ponieważ jest cicho tylko na zewnątrz, a nie wie, jak śpiewać wewnętrznie, ponieważ język człowieka ukrytego nie jest jeszcze zdolny do tego, aby gaworzyć.

W taki bowiem sposób, w jaki patrzysz na niemowlę czy małe dziec$\mathrm{ko}^{40}$, w taki sam sposób powinieneś patrzeć na dziecko, które jest wewnątrz ducha. Tak jak milczący jest język dziecka, które jeszcze nie zna słów, i ten [jego] język położony we wnętrzu ust nie zna jeszcze ruchów (powodujących) powstawanie słów, tak samo jest z językiem, który jest w twoim umyśle: jest milczący. [Nie ma] żadnych słów i żadnych myśli, jest tam położony, gotowy do tego, aby nauczyć się duchowej mowy, [zaczynając od] gaworzenia.

5. Jest zatem cisza języka

i jest cisza całego ciała,

i jest cisza duszy,

i jest cisza umysłu,

i jest również cisza ducha.

Cisza języka jest wówczas, gdy nie jest pobudzany do mówienia złych rzeczy ${ }^{41}$.

Cisza całego ciała jest wówczas, gdy żaden ze zmysłów nie jest [niczym] zajęty.

Cisza duszy jest wówczas, gdy nie wybuchają w niej nienawistne myśli.

Cisza umysłu jest wówczas, kiedy nie rozważa żadnej szkodliwej ${ }^{42}$ wiedzy czy mądrości ${ }^{43}$.

38 W tekście syryjskim posłużono się rzeczownikiem rołe ('cisza'). Por. Thesaurus, 4358. Czasownik o tym rdzeniu (ع ع) oznacza czynność zamilknięcia, uspokojenia, ustania.

39 BM Add. 12.167 ma tutaj ,jest bezczynny i złe myśli przychodzą do niego".

40 W tekście syryjskim mamy terminy حم i i oznaczające odpowiednio "embrion, płód, niemowlę' (Thesaurus, 2832-2833) i 'dziecko, niemowlę' (por. Thesaurus, 1596).

41 British Library Or. 6714: ,złych i okrutnych rzeczy albo do wypowiadania czegoś pełnego gniewu, albo skłaniającego do tworzenia problemów, albo do kalumnii czy oskarżeń".

42 BM Add. 12.167 ma wariant „złożonej”.

43 W tekście syryjskim użyto słowa Rłu.to ('wiedza, nauka, doktryna' - Thesaurus, 1559-1560) i słowa wحמל א ('mądrość' - por. Thesaurus, 1267-1268). 
Cisza ducha jest wówczas, kiedy umysł jest wolny również od wszelkich poruszeń [powodowanych przez] stworzenia duchowe, a wszelkie jego poruszenia są powodowane tylko przez Istnienie ${ }^{44}$, przez zdumienie się ciszą, która jest wokół Niego.

6. To są właśnie miary i stopnie, które znajdujemy w ciszy i w mowie. Ale jeśli jeszcze ich nie osiągnąłeś i ciągle znajdujesz się daleko od nich, pozostań tam, gdzie jesteś, i śpiewaj Bogu, używając głosu i języka, w miłości i ze czcią. I śpiewaj z zaangażowaniem, i trudź się w twojej służbie, dopóki nie osiągniesz miłości. Stój z uwielbieniem przed Panem, we właściwy sposób, [ponieważ] w ten sposób będziesz uznany za godnego kochania Go naturalną miłością, Jego, który został nam dany jako nasze odnowienie $^{45}$.

7. I kiedy recytujesz słowa modlitwy, jaką napisałem tobie, nie recytuj ich tylko po to, żeby je powtórzyć, ale tak żebyś ty sam stał się tymi słowami. Nie ma żadnej korzyści w recytowaniu, jeśli te słowa nie wcielą się W ciebie ${ }^{46}$ i nie staną się działaniem. W ten sposób stajesz się, widzialnym w całym świecie, człowiekiem Boga - Jemu niech będzie chwała i honor, i wielkość na wieki wieków. Amen.

Z języka syryjskiego przełożył, wstępem i przypisami opatrzył Tomasz Szymczak OFMConv ${ }^{47}$

44 Jan Samotnik posługuje się tutaj pojęciem rhałor ('substancja, esencja, wieczność') używanym w literaturze syryjskiej również w odniesieniu do Boga (por. Thesaurus, 173). Por. również S.P. Brock - G.A. Kiraz, «ła丸or, Gorgias Concise Syriac-English, English-Syriac Dictionary, Piscataway 2015, w: sedra.bethmardutho.org (10.12.2019): „being, essence, existence; Divine Being, Godhead”.

45 Syryjski termin Kdis ('odnowienie, inicjacja, renowacja' - por. Thesaurus,

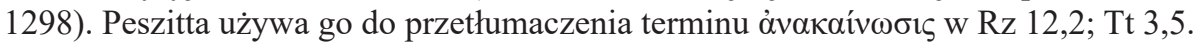

46 Można byłoby również oddać zwrotem „nie staną się tobą” lub „nie przyobleką się w ciebie".

47 Tomasz Szymczak OFMConv, doktor nauk biblijnych. W grudniu 2017 roku obronił w Papieskim Instytucie Biblijnym pracę doktorską pt. La ricezione del vangelo di Matteo nella Vetus Syra (ukazała się ona w serii Analecta Biblica w 2019 roku). Wykładowca Papieskiego Wydziału Teologicznego Świętego Bonawentury „Seraphicum” w Rzymie. Wykłada również na ISCSM Papieskiego Uniwersytetu Urbaniana w Rzymie, e-mail: t.szymczak@urbaniana.edu; ORCID: 0000-0002-7891-1643. 